\title{
ANALISIS TEOLOGIS MENGENAI BERIBADAH DI RUMAH DI TENGAH PANDEMI COVID-19 DI INDONESIA
}

\author{
Alexander Stevanus Lukuhay \\ Sekolah Tinggi Teologi Parakletos Tomohon \\ Alexanderstevanus03@gmail.com
}

\begin{abstract}
Case COVID-19 (coronavirus) has become a global pandemic, specifically in Indonesia. To break the chain of spreading of the virus, the government and church leaders carry out a social distancing process by encouraging church members to do worship in their homes. This suggestion raises the pros and cons of the congregation. Most of the congregations have a dilemma about it. It is unusual worship, for they always do worship in church. Therefore, they need a theological answer as to whether worshiping at home is acceptable or not. This research aims to answer that dilemma by exploring the concept of worship in the Bible. The method used is a hermeneutic method with a textual and historical critique approach. As the result, worship at home does not reduce the essence of worship itself because the meaning of true worship is human life itself before God (Rom 12: 1-2). It should answer the pros and cons among congregation members about worship at home during the coronavirus pandemic
\end{abstract}

Keywords: Theological Analysis, Worship at Home, Pandemic of COVID-19

\begin{abstract}
Abstrak. Kasus COVID-19 (virus corona) sudah menjadi pandemi global, secara khusus di Indonesia. Untuk memutus rantai penyebaran virus, pemerintah dan pimpinan gereja melakukan proses social distancing dengan menghimbau warga gereja melaksanakan ibadah di rumah masing-masing. Hal ini menimbulkan dilema di kalangan anggota jemaat karena selama ini mereka selalu beribadah di gereja. Mereka membutuhkan jawaban teologis apakah beribadah di rumah dapat diterima atau tidak. Penelitian ini bertujuan untuk memberikan jawaban tersebut. Metode yang digunakan adalah hermeneutika dengan pendekatan kritik teks dan kritik historis. Hasil penelitian adalah adalah bahwa pelaksanaan ibadah di rumah tidak mengurangi esensi ibadah itu sendiri, karena makna dari ibadah yang sejati adalah hidup manusia itu sendiri di hadapan Allah (Rm 12: 1-2). Dengan demikian sudah menjawab dilema yang terjadi mengenai penerapan ibadah di rumah saat pandemi COVID-19 di Indonesia.
\end{abstract}

Kata Kunci : Analisis Teologis, Ibadah di Rumah, Pandemi COVID-19

Kasus virus "corona" atau "COVID-19" sudah menjadi pandemi

global. Virus ini terdeteksi awal di Wuhan, China, pada Desember 2019, kemudian berkembang pesat sehingga banyak korban jiwa di seluruh dunia, termasuk di Indonesia (Yuliana, 2020). Menurut Pradanti, salah satu penyebab cepatnya penyebaran virus yang segolongan dengan sars dan MERS CoV ini adalah banyaknya riwayat perjalanan internasional. (Pradanti, 2019). Dalam perkembangan terakhir, total kasus yang 
terkonfirmasi positif COVID-19 terus mengalami peningkatan yang signifikan, khususnya di Indonesia. Per 30 April 2020 kasus di Indonesia telah mencapai 10.118. (Gugus Tugas COVID-19, 2020).

Menyikapi hal tersebut, salah satu solusi yang diterapkan untuk memutus mata rantai penyebaran dan penularan COVID-19 adalah "social distancing". Penerapan social distancing pada dasarnya adalah cara menjaga jarak sosial yaitu dengan menghindarkan diri dari keramaian atau tempat perkumpulan. Setelah sebelumnya pemerintah pusat mengumumkan untuk "libur" bagi seluruh instansi dan lembaga dan menggantikannya dengan layanan yang bersifat "online", kini pemerintah memutuskan bahwa proses social distancing juga diterapkan dalam konteks beribadah. Ini tercantum, antara lain, dalam Maklumat Kepala Kepolisian Negara Republik Indonesia No. Mak/2/II/2020 Tentang Kepatuhan Terhadap Kebijakan Pemerintah Dalam Penanganan Penyebaran Virus Corona (COVID 19). (Kapolri, 2020).

Gereja-gereja di Indonesia pun segera menindaklanjutinya. Persekutuan Gereja-gereja di Indonesia (PGI) per tanggal 16 Maret 2020 mengeluarkan himbauan kepada anggota-anggotanya untuk melakukan ibadah di rumah. Menurut Ketua PGI, Gomar Gultom, "Ibadah di tengah keluarga tidak mengurangi nilai hakiki dari sebuah persekutuan ibadah". (Liputan6.com, 2020). Gereja Pantekosta di Indonesia (GPdl) juga mengeluarkan surat maklumat yang menegaskan untuk menunda semua kegiatan yang bersifat komunal termasuk ibadah, dan ibadah dapat 
dilakukan di rumah masing-masing. (GPdl, 2020). Gereja Sidang Jemaat Allah (GSJA) juga mengeluarkan surat himbauan dalam Himbauan BPP GSJA No. 1830/BPP/S/3/2020 tentang himbauan untuk beribadah secara live streaming nonline atau ibadah yang dilakukan di rumah. (BPP GSJA, 2020).

Ini berarti semua ibadah dilaksanakan di rumah, termasuk ibadahibadah yang selama ini dilaksanakan di gedung gereja. Hal ini sempat menuai pro-kontra di kalangan gereja. Tanggal 24 Maret 2020, media online DetikNews.com melaporkan Gereja Pentakosta di Indonesia (GPdl) Menganti Gresik tetap menjalankan ibadah Minggu di gereja Gubernur Jawa Timur telah mengumumkan status darurat COVID-19 untuk Jawa Timur. Hal itu kemudian membuat Ketua umum Persekutuan Gerejagereja Indonesia (PGI), Gomar Gultom, menyatakan bahwa GPdl Menganti Gresik telah mengabaikan himbauan pemerintah. (Widiyana, 2020).

Media online www.kumparan.com pada tanggal 22 Maret 2020 memuat thread seorang pendeta bernama Gina Presya Budiman dari Manado yang menceritakan adanya kritik dari kalangan jemaat terhadap pesan pastoral sinode Gereja Masehi Injili Minahasa untuk beribadah di rumah. Ada yang mengatakan itu berarti pendeta lebih takut kepada virus corona daripada kepada Tuhan dan kurang beriman. Pendeta ini menjawab bahwa ibadah di rumah masing-masing sebagai bentuk pencegahan virus corona. (Kumparan.com, 2020). Handoko 
mengungkapkan bahwa anjuran pemerintah untuk beribadah di rumah memang telah menimbulkan pro dan kontra di kalangan pemimpin gereja, jemaat dan organisasi gereja (sinode). (Handoko, 2020).

Pro kontra mengenai ibadah di rumah tampaknya menimbulkan dikotomi pemahaman antara iman dan hikmat. Di satu sisi ada kalangan yang menganggap gereja perlu berhikmat dengan menaati himbauan pemerintah untuk beribadah di rumah dengan tujuan untuk mengurangi resiko penularan dan penyebaran virus corona. Tetapi di sisi lain ada kalangan pemimpin maupun warga gereja yang menganggap bahwa keputusan beribadah di rumah adalah tindakan yang tidak memiliki iman karena orang Kristen dianggap takut dan kalah dari virus corona.

Menurut Tison \& Jadi, banyak orang Kristen tidak dapat memahami makna ibadah yang sejati dan beranggapan bahwa ibadah hanyalah sebuah rutinitas. (Tison \& Djadi, 2013). Artinya, sangat mungkin telah terjadi kesalahpemahaman di kalangan umat Kristen tertentu tentang makna ibadah yang sesungguhnya. Karena itu pemahaman yang benar mengenai ibadah yang sejati perlu digali karena sebenarnya, seperti dikemukakan Rantesalu, ibadah merupakan kebutuhan dasar manusia untuk mendekatkan diri kepada Tuhan. (Rantesalu, 2019).

Penelitian ini bertujuan untuk menemukan makna ibadah yang sesungguhnya dalam teologi Kristen yang didasarkan pada Firman Tuhan. Dengan menggali dasar teologis baik secara etimologis maupun historis, maka secara tidak langsung akan ditemukan konsep teologi ibadah yang 
esensial dan akan menjadi "fondasi" penerapan ibadah yang sejati (bnd. Yes 43: 22-28; Rm 12: 1-2) di saat makna ibadah itu sendiri sudah banyak tergerus oleh "pencitraan ritus" yang mengedepankan eksistensi normatif . Kajian ini diharapkan dapat memberikan jawaban terhadap pro-kontra mengenai penerapan ibadah di rumah di tengah pandemi COVID-19.

\section{METODE}

Metode yang digunakan dalam penelitian ini adalah metode penelitian kualitatif. Penelitian kualitatif adalah prosedur penelitian yang menghasilkan data deskriptif berupa kata-kata tertulis atau lisan dari orang-orang dan perilaku yang dapat diamati. Penelitian ini dilaksanakan dengan sifat pragmatis (konstruktif) dimana salah satu sifat dasarnya adalah dapat bermanfaat bagi banyak orang (Winata, 2014). Dalam penelitian kualitatif yang berhubungan dengan penafsiran Alkitab, penelitian ini dilakukan dengan menggunakan metode hermeneutik. Menurut Purba, metode hermeneutik adalah suatu metode yang digunakan untuk menyikap, menjelaskan, mengintepretasi dan menerjemahkan makna dari teks-teks Alkitab sehingga isinya dapat dipahami oleh umat. (Purba, 2018). Dikarenakan penelitian ini bertujuan menggali makna ibadah secara teologis (baik teks maupun historis), sehingga metode hermeneutika Alkitab ini sangat tepat untuk digunakan.

Teknik pengambilan data dilakukan dengan cara menggali teksteks Alkitab yang menjadi acuan bagi penafsiran. Teks yang diambil adalah teks mengenai ibadah baik berdasarkan makna kata dasar 
maupun pergerakan sejarah dan progresivitas ibadah itu sendiri dalam Alkitab yang ditinjau dari Perjanjian Lama maupun Perjanjian Baru. Dalam menganalisis data penelitian, penulis menggunakan pendekatan kritik taks dan kritik historis (historical criticism/ high criticism). Dalam kritik teks, penulis berusaha untuk menggali secara terperinci teks dasar (ibadah) sehingga ditemukan makna yang terkandung dari teks itu sendiri (ibadah). Sedangkan kritik historis digunakan untuk menganalisis data teks (ibadah) berdasarkan perspektif sejarah sehingga ditemukan makna sebenarnya dari ibadah itu sendiri.

Berdasarkan analisis data teks maupun historis, peneliti akan menghubungkannya dengan persoalan beribadah di rumah sebagai upaya pemerintah dan pemimpin gereja menerapkan social distancing di tengah pandemi global COVID-19. Dari hasil analisis data teks Alkitab mengenai ibadah, peneliti akan menarik makna ibadah tersebut untuk; 1) menjadikannya dasar teologis mengenai beribadah di rumah di tengah pandemi COVID-19 dan, 2) Membangun argumen dalam menjawab pro dan kontra yang terjadi mengenai permasalahan penerapan ibadah di rumah.

\section{HASIL}

\section{Teologi Ibadah dalam Alkitab}

Secara etimologis, ibadah merupakan bentuk sikap dan tindakan secara fisik yang tunduk dan menyembah Allah yang merupakan suatu 
ungkapan emosi dari dalam hati manusia sebagai bentuk rasa hormat, suatu ketundukan, ketidakberdayaan, menyembah, melayani, menghamba dan bentuk pengharapan manusia kepada Allah.

Dalam Perjanjian Lama, konsep ibadah berkembang sesuai dengan konteks bangsa Israel dan bagaimana Allah bekerja di tengah-tengah bangsa itu, yaitu mulai dari penerapan korban, konsep Kemah Suci dan Bait Suci. Dalam Perjanjian Baru, konsep ibadah lebih progresif dan tak terikat oleh hal-hal yang bersifat normatif, seperti liturgi, Bait Allah atau Sinagoge. Tekanan yang dihadapi orang percaya pada masa itu membuat ibadah lebih dimaknai secara fundamental sebagai bentuk persembahan tubuh kepada Allah (Yes 43: $22-28$ bnd. Rm 12: 1-2) dan bentuk pelayanan yang misioner dan menyentuh seluruh aspek hidup manusia.

\section{Teologi Ibadah sebagai Dasar Penerapan Ibadah di Rumah}

Pro dan kontra yang terjadi mengenai di kalangan pemimpin gereja dan jemaat mengenai penerapan ibadah di rumah di tengah pandemi COVID-19 telah menimbulkan dikotomi pemahaman antara iman dan hikmat. Berdasarkan analisis kritis teologis, pro dan kontra ini perlu diakhiri dan sebagai warga gereja yang beribadah dan tunduk kepada Allah maka hal itu juga perlu ditunjukkan dengan ketundukan kepada pimpinan gereja dan pemerintah sebagai wakil Allah di dunia ( $\mathrm{Rm}$ 13: 1-7 bnd. Kol. 3: 22). Pemerintah dan pemimpin gereja pada dasarnya mengambil keputusan bukan untuk "menutup gereja" atau "meniadakan peribadatan", tetapi 
merubah konsep ibadah itu sendiri demi kepentingan yang urgen dan general menyangkut hidup manusia.

Keputusan ini bukanlah menunjukkan kadar iman dari pimpinan gereja (sinode) atau masalah penekanan ketaatan yang lebih tinggi kepada pemerintah daripada Tuhan. Social distancing yang diterapkan dalam konteks peribadatan dilakukan sebenarnya untuk menunjukkan nilai dan esensi dari iman dan ibadah itu sendiri. Kadar iman tidak dapat diukur hanya pada "mujizat yang adikodrati". Kepedulian kepada sesama dan upaya mewujudnyatakan Kerajaan Allah di tengah pandemi global ini sebenarnya adalah esensi dari iman seseorang yang beribadah kepada Allah.

Penyebaran dan penularan virus corona yang cepat dan banyak "memakan" korban jiwa di kalangan lanjut usia dan yang memiliki riwayat penyakit kronis membuat pemerintah dan pimpinan gereja mengambil keputusan untuk menerapkan konsep beribadah di rumah. Ini harus dimaknai sebagai ungkapan iman, kasih dalam ibadah yang esensial yaitu kepedulian kepada orang lain demi kepentingan yang lebih besar (Mat. 22: 37-40).

Ibadah dalam maknanya adalah hidup dan hubungan manusia secara pribadi dengan Allah. Allah yang dinamis bergerak dalam ibadah manusia yang progresif menunjukkan bahwa ibadah tidak dibatasi oleh ruang dan waktu. Ibadah yang sejati melalui persembahan hidup kepada Allah yang teraplikasi dalam kepedulian kepada sesamanya adalah 
ungkapan iman orang percaya. Jadi di manapun dan kapan pun ibadah dilaksanakan, tidak akan merubah nilai dan esensi ibadah itu sendiri selama manusia memiliki hubungan yang erat dengan Allah dan teraplikasi dalam kepedulian dengan sesamanya.

Saat pemerintah dan pemimpin gereja menghimbau serta menerapkan ibadah di rumah sebagai upaya social distancing di tengah pendemi global, warga gereja perlu merespons positif dengan mematuhinya. Secara teologis, ibadah di rumah adalah kesempatan membangun kembali konsep ibadah yang sejati, suatu konsep yang fundamental di tengah konteks pandemi global. Ibadah bukan sesuatu yang eksistensi dan normatif saja, tetapi warga gereja harus menyadari esensi dari ibadah itu sendiri sebagai suatu sikap hati, ketundukan kepada Allah dan pelayanan yang menyentuh aspek hidup manusia untuk menghadirkan Kerajaan-Nya di muka bumi.

Di mana pun ibadah dilaksanakan, entah di gereja, di rumah, atau di tempat lain, bukanlah ukuran yang dapat dijadikan indikator untuk mengukur seseorang telah beribadah kepada Allah. Jika secara historis konsep ibadah itu berubah secara progresif sesuai konteks, maka tidaklah salah jika peribadatan di tengah pandemi COVID-19 ini dilaksanakan di rumah masing-masing, karena Allah-pun secara historis hadir, bekerja dan menyertai umat-Nya dalam konteks tertentu (bnd. Mat. 18: 20).

Perubahan konsep ibadah di tengah pandemi ini pada dasarnya tidaklah merubah makna ibadah secara esensial, tetapi sebenarnya 
adalah upaya untuk mengembalikan nature dari makna ibadah itu sendiri yang telah mengalami degradensi makna. Jadi sudah sepatutnya warga gereja sebagai orang percaya memberi respons positif keputusan pemerintah dan pimpinan gereja untuk merubah konsep beribadah yang normatif ini kepada ibadah di rumah masing-masing. Momen ini sebenarnya adalah kesempatan gereja merekonstruksi ulang konsep beribadah yang Alkitabiah.

\section{PEMBAHASAN}

Istilah ibadah itu sendiri dalam Perjanjian Lama memiliki beberapa makna. Kata ini, menurut Christimoty, berasal dari kata "shahah"/ "shachah" yang memiliki arti menekan, membungkuk, menyembah. Makna ibadah ini bukan hanya diartikan sebagai bentuk sikap dan tindakan secara fisik yang tunduk dan menyembah Allah, tetapi lebih dari itu adalah suatu ungkapan emosi yang keluar dari dalam hati manusia sebagai bentuk rasa hormat, ketundukan dan bentuk pengharapan manusia kepada Allah (Kej 23: 7, 24: 52; Kel 4: 31). Istilah lain yang dipakai dalam ibadah adalah kata "sagad" yang memiliki arti suatu keadaan yang tidak berdaya atau ketidakberdayaan (Yes 44: 19, 46: 6). Kata ini pada dasarnya diartikan sebagai menyembah. Selain itu, kata ibadah dalam Perjanjian Lama juga dipakai istilah "abad" atau "abodah" yang memiliki arti "melayani", "menghamba" atau "aktivitas yang mengakui dan menghargai seseorang" (2 Raj 10: 19, 21; Yes 19: 21, 23). (Christimoty, 2019). 
Sementara itu dalam Perjanjian Baru, pengertian ibadah berasal dari bahasa Yunani "latreia" yang memiliki arti pekerja, upahan, pelayan dan mengabdi. (Sumarto, 2019). Definisi ibadah dalam Perjanjian Baru dihubungkan dengan kata dalam bahasa Yunani, yaitu "proskuneo" yang berarti "mencium tangan" atau "merendahkan dir". (Christimoty, 2019). Ibadah dalam Perjanjian Baru merupakan suatu pelayanan yang dipersembahkan kepada Allah, yang tidak hanya dibatasi pada suatu bentuk ibadah di Bait Allah (leiturgos: Yun), tetapi juga merupakan bentuk pelayanan kepada sesama (diakonos: Yun) (Mat. 5: 23; Luk. 10: 25; Yoh. 4: 20-24; Yak. 1: 27). (Widyatmadja, 2012).

Secara historis, konsep ibadah dan hubungannya dengan "rumah ibadah" berubah-ubah dan mengalami perkembangan sesuai dengan konteks keberadaan bangsa Israel. Konsep ibadah dalam Perjanjian Lama awalnya sangat berhubungan dengan persembahan korban (Kej. 4: 3-4). Menurut Singgih, persembahan korban (hasil bumi) yang dilakukan dengan cara membakar korban persembahan adalah bentuk tradisi dan pemujaan kepada "yang Ilahi" yang berisi rasa syukur dan hormat kepada kuasa yang melebihi diri manusia itu (kuasa metafisik). Selain itu, Ibadah dalam hubungannya dengan korban dimaknai sebagai upaya pendamaian antara Allah dan umat-Nya. (Singgih, 2018).

Menurut Mawene, pada kisah Musa konsep ibadah kemudian berubah dari konsep persembahan korban kepada sistem sistem peribadatan berpusat pada "Kemah Suci" (Tabernakel), yaitu suatu model 
"gedung" ibadah yang bersifat portable (dapat dibongkar pasang dan dibawa). Model kemah suci sangat cocok untuk dan sesuai dengan kebiasaan bangsa Israel yang waktu itu sedang mengembara di padang gurun. Konsep beribadah yang telah berubah ini adalah bentuk kontekstual yang tidak bisa dilepaskan dari sifat Yahweh yang pada saat itu dikenal sebagai Allah yang dinamis dan terus bergerak untuk menyertai umat-Nya di padang gurun.(Mawene, 2012).

Setelah bangsa Israel pada akhirnya menetap di tanah Kanaan, Yahweh juga dipandang sebagai Allah menetap dan diam bersama dengan umat-Nya, sehingga kemudian pada masa Salomo dibangunlah sebuah bangunan permanen yang menjadi pusat peribadatan Israel menggantikan kemah Suci (1 Raj. 5 \& 6). Bangunan itu kemudian disebut sebagai "Bait Allah" (habayit ha'elohim). (Mawene, 2012). Menurut Kristianto, di dalam kehidupan beragama bangsa Israel, tempat ibadah memainkan peran yang penting dan sentral. Hal ini dikarenakan tempat ibadah adalah perlambangan kehadiran Allah. (Kristianto, 2016).

Dalam Perjanjian Baru, ibadah dimaknai sebagai penyataan diri Allah kepada manusia melalui Yesus Kristus dan manusia menaggapinya melalui sikap dan tindakan dalam kehidupan sehari-hari. Ibadah dalam maknanya adalah suatu bentuk pelayanan inklusif dan multi-dimensional yang merupakan upaya umat Allah untuk hidup melayani di tengah-tengah dunia. Ibadah merupakan suatu pekerjaan atau keikutsertaan orang 
percaya dalam pekerjaan Tuhan untuk mengubah dan menyelamatkan dunia demi kemuliaan Tuhan.

Yesus dalam kisah-kisah Perjanjian Baru tidak menekankan ibadah sebagai suatu tempat. Dahill mengungkapkan bahwa ibadah adalah sebuah pastisipasi umat dalam misi Allah untuk dapat memberikan kehidupan kepada dunia untuk menjadi tempat dimana Roh ke dalam realitas nyata kehidupan kebangkitan dan kasih dicurahkan untuk semua dalam Yesus Kristus. (Dahill, 2016). Pasca era kehadiran Yesus di muka bumi, konsep ibadah dalam Perjanjian Baru adalah bentuk ibadah yang dilaksanakan oleh orang percaya. Bentuk ibadah biasanya dilaksanakan di rumah-rumah, dan kesederhanaan merupakan ciri khas pelayanan (ibadah) rumah tangga. Konsep ibadah jemaat mula-mula yang dilakukan di rumah-rumah merupakan bentuk persekutuan yang dilakukan oleh orang-orang percaya yang dipanggil bukan untuk mempersembahkan korban tetapi untuk memberitakan Injil lewat perkataan dan perbuatan baik terhadap Tuhan maupun sesama manusia.

Berbicara mengenai keputusan merubah konsep ibadah yang normatif (di rumah gereja) kepada konsep beribadah situasional (rumah masing-masing) haruslah dipahami dengan pemikiran yang kritis dan teologis. Oleh karena itu, perubahan konsep ibadah yang diputuskan oleh pemerintah dan pimpinan gereja sebenarnya bukanlan suatu persoalan yang mendasar apalagi harus diperdebatkan. Penerapan ibadah di rumah selama pandemi hanyalah bagian dari upaya para pemimpin yang peduli 
kepada rakyatnya, para pemimpin gereja yang mengasihi umat yang digembalakannya.

Pandemi COVID-19 yang berdampak kepada munculnya keputusan beribadah di rumah ini harus ditanggapi dengan respons yang positif. Ini sebenarnya adalah kesempatan bagi gereja yang adalah pribadi orang percaya itu sendiri untuk merekonstruksi ulang dan membangun kembali konsep ibadah yang esensial dan fundamental yaitu suatu konsep ibadah yang tidak dibatasi oleh hal-hal yang fisik (ruang, waktu, dIl). Dalam Alkitab dinyatakan bahwa ibadah adalah kehidupan dan hubungan manusia itu dengan Allah dalam suatu sikap hidup yang tunduk dan menyembah Dia. Menurut Wijaya, ibadah merupakan perjumpaan dengan Tuhan melalui penyembahan, sikap hati yang benar dan mengalami Tuhan secara pribadi. (Wijaya, 2015).

Pelaksanaan ibadah di rumah-pun secara biblical-historis pernah terjadi baik dalam kisah Perjanjian Lama maupun dalam Perjanjian Baru. Konsep korban sebagai ibadah awal secara tersirat menggambarkan ibadah yang bersifat pribadi, dimana manusia mengungkapkan rasa syukurnya kepada "Sang Pencipta". Selain itu dalam kisah pelayanan Yesus maupun pasca-Yesus model ibadah di rumah sudah menjadi hal yang biasa, terutama pada masa-masa penganiayaan orang Kristen mulamula. Jadi sebenarnya tidak ada yang baru atau yang berubah secara historis mengenai ibadah itu sendiri. Oleh karena itu, penting membangun kembali teologi ibadah dalam konteks bergereja dan bermasyarakat, 
sehingga akan membentuk kembali pemahaman dasar mengenai ibadah dan membangun konstruksi ibadah yang kontekstual dan menjawab tantangan zaman.

Di tengah-tengah perjuangan bangsa Indonesia untuk terlepas dari pandemi COVID-19, yang seharusnya menjadi pergumulan bersama gereja adalah bagaimana menghidupkan konsep ibadah yang sejati dalam kerangka berpikir yang dibangun atas kepedulian kepada sesama. Dalam hal ini ibadah dipahami sebagai suatu kepedulian dan kasih, serta upaya untuk menghadirkan "Kerajaan Allah" di muka bumi. Kerajaan Allah adalah tolok ukur bagi semua kegiatan manusia. Artinya bahwa ibadah dalam praktinya selain sebagai perwujudan hubungan pribadi manusia dengan "Sang Pencipta", tetapi juga adalah sebuah upaya untuk menghadirkan Kerajaan Allah yang tercermin dari kehidupan gereja dalam konteks dan realitas sosial dimana gereja itu hidup dan berdiri.

Menurut Widyadmatdja, Kerajaan Allah bukan saja dipahami sebagai "kerajaan dengan kuasa" yang menitikberatkan pada hubungan yang vertikal antara manusia dan "Sang Khalik", tetapi lebih daripada itu Kerajaan Allah (Yun: basilea ton theo) adalah upaya mewujudnyatakan tanda-tanda kedatangan pemerintahan Allah di tengah dunia. (Widyatmadja, 2012). Ibadah dalam kerangka berpikir Kerajaan Allah bukanlah sesuatu ritual dalam kuil yang bersifat normatif, tetapi merupakan upaya menyampaikan pesan Injil ke dalam konteks dan membawa transformasi hidup. 
Ibadah di rumah selama pandemi COVID-19 adalah upaya gereja untuk turut serta mewujudnyatakan Kerajaan Allah di muka bumi. Kerajaan Allah merupakan tugas dan panggilan gereja yang berupaya untuk mengusahakan kehidupan yang damai dan sejahtera. Multipemahaman yang muncul dari keanekaragaman dan kepelbagaian pemikiran dan budaya, serta kepentingan hendaknya tidak menjadi suatu perdebatan yang merusak kesatuan gereja, tetapi berbagai pemahaman itu harus dapat diselaraskan dengan mengedepankan komunikasi yang efektif, (Pattipeilohy, 2018), sehingga pemikiran gereja di tengah pandemi ini bersatu dalam upaya mewujudkan kepedulian kepada sesama yang berimbas pada pewujudnyataan Kerajaan Allah di bumi Indonesia.

\section{KESIMPULAN}

Dari hasil penelitian dan pembahasan penelitian yang telah diuraikan di atas, maka peneliti menyimpulkan bahwa konsep beribadah di rumah sebagai upaya social distancing di tengah pandemi COVID-19 ini adalah keputusan yang tepat dan memiliki dasar teologis yang jelas. Ibadah di rumah bukanlah suatu upaya untuk "merusak" esensi ibadah itu sendiri. Secara literer, Alkitab memberikan dasar dan bukti yang kuat mengenai ibadah di rumah. Ibadah merupakan suatu persembahan hidup manusia dengan Allah secara pribadi dalam ketundukan dan penyembahan. Sedangkan secara historis pelaksanaan ibadah pribadi atau di rumah bukanlah hal yang baru, tetapi hal yang pernah terjadi 
dalam kisah-kisah Alkitab, karena sifat ibadah pada dasarnya adalah progresif.

Menjawab pro dan kontra di kalangan pemimpin gereja maupun jemaat mengenai keputusan beribadah di rumah, secara teologis, beribadah di rumah bukanlah menunjukkan kelemahan iman orang Kristen, tetapi sebaliknya menunjukkan kekuatan iman dengan membangun kepedulian kepada sesama terutama di tengah pandemi COVID-19 yang menyerang bangsa Indonesia. Di sinilah peran gereja yang taat kepada pemerintah dan pemimpin agama untuk berupaya membangun kasih, kepedulian dan mengusahakan kehadiran Kerajaan Allah di bumi Indonesia.

Beribadah di rumah tidak dimaknai sebagai upaya mengesampingkan rumah gereja (di tengah pandemi global), tetapi sebagai tempat berkumpul dan beribadah umat Tuhan. Pemahaman yang harus dibangun adalah: 1) Merekonstruksi secara teologis kembali makna ibadah kepada esensi dan nature dari badah itu sendiri. 2) Mengusahakan dan membangun konsep ibadah yang kontekstual, inklusif-holistik dan bertujuan menjawab realitas sosial demi terwujudnya Kerajaan Allah.

\section{DAFTAR PUSTAKA}

BPP GSJA. (2020). Surat Himbauan BPP GSJA No. 1830/BPP/S/3/2020 tentang himbauan untuk beribadah secara live streaming online atau ibadah yang dilakukan di rumah.

Christimoty, D. N. (2019). Teologi Ibadah dan Kualitas Penyelenggaraaan lbadah: Sebuah Pengantar. Pasca: Jurnal Teologi Dan Pendidikan Agama Kristen, 15(1), 1-7. 
Dahill, L. E. (2016). Life in All Its Fullness: Christian Worship and the Natural World. Liturgy, 31(4), 43-50. https://doi.org/10.1080/ 0458063X.2016.1194684

GPdl. (2020). Maklumat Gereja Pantekosta di Indonesia (GPdl) No. 014/MD-Mt/III-2020.

Gugus Tugas COVID-19. (2020). Gugus Tugas Percepatan Penanganan COVID-19. Https://Covid19.Go.Id/. https://covid19.go.id/

Handoko, Y. T. (2020). Virus Corona Covid-19: Perlukah Ibadah Online? Reformed Exodus Community. http://rec.or.id/article_1111_VirusCorona-Covid-19:-Perlukah-Ibadah-Online

Kapolri. (2020). Maklumat Kepala Kepolisian Negara Republik Indonesia No. Mak/2/III/2020 Tentang Kepatuhan Terhadap Kebijakan Pemerintah Dalam Penanganan Penyebaran Virus Corona (COVID 19.

Kristianto, S. (2016). "YESUS SEBAGAI PENGGENAP TEMPAT IBADAH" DALAM INJIL YOHANES. Jurnal Theologi Aletheia, 18(10), 132-150.

Kumparan.com. (2020). Pesan Sejuk Pendeta di Manado soal Ibadah Gereja Pindah di Rumah Akibat Corona. Kumparan.Com. https://kumparan.com/manadobacirita/pesan-sejuk-pendetadimanado-soal-ibadah-gereja-pindah-di-rumah-akibatcorona1t4eefD6UGb/full

Liputan6.com. (2020). PGI Imbau Tiadakan Ibadah di Gereja Selama Dua Pekan. Liputan6.Com. https://www.liputan6.com/news/read/4206760/ pgi-imbau-tiadakan-ibadah-di-gereja-selama-dua-pekan\#

Mawene, M. T. (2012). Perjanjian Lama dan Teologi Kontekstual. BPK Gunung Mulia.

Pattipeilohy, S. Y. E. (2018). Ketuhanan yang Berkebudayaan: Memahami Pancasila sebagai Model Interkulturalitas. GEMA TEOLOGIKA, 3(2), 121. https://doi.org/10.21460/gema.2018.32.363

Pradanti, D. S. (2019). EVALUATION OF FORMAL RISK ASSESSMENT IMPLEMENTATION OF MIDDLE EAST RESPIRATORY SYNDROME CORONAVIRUS IN 2018. Jurnal Berkala Epidemiologi, 7(3), 197. https://doi.org/10.20473/jbe.v7i32019.197-206

Purba, D. W. (2018). HERMENEUTIKA SEBAGAI METODE PENDEKATAN DALAM TEOLOGI. Regula Fidei, 3(1), 520-530. https://doi.org/10.33541/REGULA FIDEI.V311.978 
Rantesalu, M. B. (2019). ANALISIS TENTANG PEMAHAMAN IBADAH MENURUT MAZMUR 50 PADA MAHASISWA STAKN KUPANG. VISIO DEI: JURNAL TEOLOGI KRISTEN, 1(2), 222-238. https://doi.org/10.35909/visiodei.v1i2.50

Singgih, E. G. (2018). Korban dan Pendamaian: Studi lintas ilmu, lintas budaya, dan lintas agama mengenai upaya manusia menghadapi tantangan terhadap kehidupan di luar kendalinya (R. U. NapitupuluSimarangkir (Ed.)). BPK Gunung Mulia.

Sumarto, Y. (2019). Tinjauan Teologis Tentang Ibadah Bagi Pelaksanaan Misi Allah. Jurnal Jaffray. https://doi.org/10.25278/jj71.v17i1.312

Tison, T., \& Djadi, J. (2013). Pengajaran Tentang Ibadah Berdasarkan Surat Ibrani 10:19-25 Dan Implimentasinya Dalam Kehidupan Orang Percaya Pada Masa Kini. Jurnal Jaffray. https://doi.org/10.25278/ jj71.v11i1.67

Widiyana, E. (2020). Ini Kata Gereja Pantekosta Menganti Tetap Ibadah di Tengah Wabah Corona. News.Detik.Com. https://news.detik.com/ berita-jawa-timur/d-4951965/ini-kata-gereja-pantekosta-mengantitetap-ibadah-di-tengah-wabah-corona

Widyatmadja, J. P. (2012). Yesus \& Wong Cilik: Praksis Diakonia Transformatif dan Teologi Rakyat di Indonesia. BPK Gunung Mulia.

Wijaya, H. (2015). Kajian Teologis Tentang Penyembahan Berdasarkan Injil Yohanes 4:24. Jurnal Jaffray, 13(1), 77. https://doi.org/10.25278/ jj71.v13i1.112

Winata, T. D. (2014). MANFAAT KAJIAN FILASAFAT, NILAI ETIKA DAN PRAGMATIS ILMU PENGETAHUAN UNTUK MELAKUKAN PENELITIAN ILMIAH. Jurnal IImiah Widya, 2(2).

Yuliana. (2020). Corona virus diseases (Covid-19): Sebuah tinjauan literatur. Wellness And Healthy Magazine, 2(187-192). 